\title{
PIF1 Gene
}

National Cancer Institute

\section{Source}

National Cancer Institute. PIF1 Gene. NCI Thesaurus. Code C137965.

This gene plays a role in the DNA maintenance. 